\title{
機械構造部品用焼結材料のヤング率について
}

\author{
黄鶴年1, 楊堅 ${ }^{1}$, 後藤 雅樹 1 , 渡辺 侊尚的 2 \\ ロ1フクイシンター(陎)，テ319-0301 静岡県富士郡芝川町上柚野 16 . \\ 的 2 早稲田大学材料技術研究所, $\bar{\top}$ 169-0051 新宿区西早稲田 2-8-26.
}

\section{Young's Modulus of Sintered Materials for Structual Machine Parts}

\author{
Hao-Nien Huang ${ }^{\not 1}$, Jian Yang ${ }^{11}$, Masaki Goto ${ }^{1 / 1}$ and Teruhisa Watanabe ${ }^{\not 2}$ \\ ${ }^{1}$ Fukui Sinter Co., Ltd., 16 Kamiyuno Shibakawa-cho, Fuji-gun, Shizuoka 319-0301. \\ ${ }^{4}$ Laboratory for Materials Science and Technology, Waseda University, 2-8-26 Nishiwaseda, Shinjuku-ku,Tokyo $169-0051$.
}

Received June16, 1998

\section{SYNOPSIS}

Method for determination of Young's modulus of sintered metal materials is dynamic testing method by the longitudinal oscillations of the specimens, which has been provided in the standard of Japan Powder Metallurgy Association JPMA M 10 in March 1997. This paper shows the testing results of Young's modulus of various sintered metal materials for machine parts of the iron base, the stainless steel base and the bronze base materials, which are introduced in Japanese Industrial Standard JIS Z 2550. For example, the specimens of the iron base $(6 \times 8 \times 60 \mathrm{~mm})$ were made from reduced iron powder, atomized iron powder, electrolytic copper powder, natural graphite powder and carbonyl nickel powder, by compressing with $300 \sim 600 \mathrm{MPa}$ and sintering at $1423 \mathrm{~K}$ for $1.8 \mathrm{ks}$ in cracked ammonia atmosphere. Consequently, the values of Young's modulus and relations between the values of Young's modulus and the sintered densities of various sintered metal materials could be obtained.

\section{KEY WORDS}

Young's modulus, sintered material, iron, stainless steel, bronze

\section{1 緒 言}

粉末冶金法による焼結機械部品の用途の約 $80 \%$ ，自動車用 を主とした輸送機械向けであって,軸受などの可動機械部品に 多く使用されている。それらの使用条件は，負荷を伴う回転な ど微小な弾性変形が周期的に生じる弾性振動下であり,求めら れる特性としては一般的な引張強さや伸びなどよりも,使用応 力範团内での使用寿命を示寸疲労強さや，その応力での歪み率 を示すヤング率の值が重要になってくる.

ヤング率は弾性率の一種で,一様な太さの棒を軸方向に引っ張 るかまたは圧縮するとき，棒の断面に働く応力を $\mathrm{T}$ ，単位長さあ たりの伸びまたは縮みを $\varepsilon$ とすると, 比例限界内で $\mathrm{T}=\mathrm{E} \cdot \varepsilon$ という 関係が成り立つが，この場合の比例定数Eをヤング率といい，縦 弾性率ともいう。この試験方法には試験中に静荷重を加えて, それによって生じる弾性変形から求める圧縮法,引張法あるい は曲げ法などの静的な方法と, 試験片に强制振動を与えて, そ の共振周波数から求める共振法あるいは超音波パルスの伝播速 度から求める超音波パルス法などの動的な方法とがある ${ }^{1,22}$.

燒結金属材料のヤング率は多孔質であるから気孔を含む材料
のヤング率であって，見掛ヤング率ともいえるが、この試験方 法は縦振動を与える動的な共振法で 1997 年 3 月に日本粉末治 金工業会の団体规格JPMA M 10 に制定された．本報ではこの 共振法を用いて日本工業規格JIS Z 2550に規定されている機械 構造用焼結材としての各種鉄系焼結合金,ステンレス鋼系焼結 合金及び青銅系焼結合金についてヤング率を測定した結果を報 告する.

\section{2 試料及び実験方法}

\section{1 実験試料}

鉄系 (SMF 1 5, 7,8 種)の主原料としては還元鉄粉 (KIP$255 \mathrm{M})$ とアトマイズ鉄粉 (KIP-300A) 用い，銅粉は電解銅粉 (CE-25), 炭素粉は天然黒鉛粉 (UCP), そしてニッケル粉はカー ボニル・ニッケル粉を用いた。これらを Table 1 に示す比率で 配合し，小型ダブルコーン・ミキサーで1.2ks 混合した，成形 は濃度 $4 \mathrm{~g} / 1$ ハステアリン酸亜鉛のアルコール溶液を内壁面に塗 布した加圧断面積 $6 \times 60 \mathrm{~mm}$ の金型を用いて，圧粉体の寸法が $6 \times 8 \times 60 \mathrm{~mm}$ になるように使用粉重量を調節して $300 \sim 600 \mathrm{MPa}$ 
Table 1 Chemical compositions of sintered materials for structual machine parts.

\begin{tabular}{|c|c|c|c|c|c|c|c|c|c|c|}
\hline \multirow{2}{*}{ Mater ial } & \multicolumn{10}{|c|}{ Chemical composition (mass\%) } \\
\cline { 2 - 10 } & Fe & C & Cu & Ni & Sn & Pb & Si & Mn & Cr & Mo \\
\hline SMF 1 & Bal. & $\leqq 0.01$ & - & - & - & - & - & - & - & - \\
SMF 2 & Bal. & $\leqq 0.01$ & $1.5 \sim 5$ & - & - & - & - & - & - & - \\
SMF 3 & Bal. & $0.4 \sim 0.8$ & - & - & - & - & - & - & - & - \\
SMF 4 & Bal. & $0.4 \sim 0.8$ & $1.5 \sim 5$ & - & - & - & - & - & - & - \\
SMF 5 & Bal. & $0.4 \sim 0.8$ & $1.5 \sim 3$ & $4 \sim 8$ & - & - & - & - & - & - \\
SMF 6 & Bal. & $\leqq 0.5$ & $10 \sim 25$ & - & - & - & - & - & - & - \\
SMF 7 & Bal. & $\leqq 0.01$ & - & $2 \sim 8$ & - & - & - & - & - & - \\
SMF 8 & Bal. & $0.4 \sim 0.8$ & - & $2 \sim 4$ & - & - & - & - & - & - \\
SMS 1 & Bal. & $\leqq 0.03$ & - & $12 \sim 15$ & - & - & $\leqq 1.0$ & $\leqq 2.0$ & $16.0 \sim 18.0$ & $2.0 \sim 3.0$ \\
SMS 2 & Bal. & $\leqq 0.03$ & - & $\leqq 0.6$ & - & - & $\leqq 1.0$ & $\leqq 1.0$ & $11.0 \sim 13.5$ & - \\
SMK 1 & - & $\leqq 1.5$ & Bal. & - & $8.5 \sim 10$ & $\leqq 2.0$ & - & - & - & - \\
\hline
\end{tabular}

で加圧した，焼結条件は $1423 \mathrm{~K} \times 1.8 \mathrm{ks}$ で，アンモニア分解ガ 又雾囲気である．鉄－炭素 (銅溶浸) 系 [SMF 6 種]の原料粉に はアトマイズ鉄粉 (KIP-300A), 天然黑鉛粉 (UCP)およびアト マイズ銅合金粉 $(\mathrm{Cu}-3 \% \mathrm{Co})$ を用いた，化学組成が $\mathrm{Fe}-0.5 \% \mathrm{C}$ になるように原料粉を配合し，ミキサーで1.2ks混合した，成 形は上記の鉄系と同様に金型を用いて，300 600MPa で加圧 した. 焼結条件は鉄系と同梯である，次に溶浸用 $\mathrm{Cu}-3 \% \mathrm{Co}$ 合 金粉を用いて，成形圧力 $200 \sim 400 \mathrm{MPa}$ で溶浸用圧粉体を作 り，これを焼結体の上にのせてアンモニア分解ガス中 $1423 \mathrm{~K}$ で保持時間 $1.2 \mathrm{ks}$ で溶浸を行った。

ステンレス鋼系の原料粉にはオーステナイト系はDAP-316L アトマイズ粉，フェライト系はDAP-410Lアトマイズ粉を用 いた，成形は鉄系と同様に，金型を用いて，500〜750MPa で加 圧した，焼結条件は $1423 \mathrm{~K} \times 1.8 \mathrm{ks}$ で，雲囲気は水素中， $10^{-5} \mathrm{Torr}$ 真空中およびアンモニア分解ガス中である．青銅系の原料粉 には，合金粉は $\mathrm{Cu}-10 \% \mathrm{Sn}$ 青銅合金粉 (LA-9)，また混合粉は 電解銅粉 (CE-8) およびアトマイズ銅粉 (Cu-At-200)を主原料粉 にしてアトマイズ錫粉(Sn-At-w-250)を配合し，更にアトマイ ズ鉛粉 (Pb-At-200) あるいは天然黒鉛粉 (UCP) 添加した. 成 形は鉄系と同様に，金型を用いて，300〜550MPaで加圧した。 焼結条件は $1043 \mathrm{~K} \times 1.8 \mathrm{ks}$ で，水素雾囲気である。

\section{2 ヤング率測定装置}

本報では動的測定法の一つである縦振動共振法を採用して いる ${ }^{3,4)}$.これはFig.1 に示すように，角棒状試験片の両端にそ れぞれ同種類の振動子が駆動器用および検出器用として取り 付けられていて，振動装置側の駆動器用振動子には增幅器お よび振動数カウンタをともなった発振器が, 測定装置側の検 出器用振動子には整流・堌幅器およびデジタル電圧計が接続 されている。まず，試験片支持台は梁より裁䋖用細口糸で 作った一対の采の輪で試験片を水平に吊り下げるものである
が,この場合，系の輪間距離の相違は共振振動数測定值に対 して影響しないことが確認されたので，系の輪間距離は約 $30 \mathrm{~mm}$ 一定とし，試験片長手方向の中央部を等しくはさんで 吊り下げることとした.

次に, ここで使用した振動装置側の駆動器用振動子は圧電 ブザー用で，構造は直径約 $20 \mathrm{~mm}$ ，厚さ的 $0.2 \mathrm{~mm}$ の PZT 素子 に直径約 $27 \mathrm{~mm}$, 厚さ約 $0.2 \mathrm{~mm}$ の黄銅板をゴム系接着郕で結 合させた「たわみ型振動子」である，発振器は正弦波を発生 して振動子を駆動させるものである，本器の測定振動数単位 は $10 \mathrm{~Hz}$ とし，発振振動数帯 $20 \sim 100 \mathrm{KHz}$ をスイープできるよ うになっている．測定装置側の検出器用振動子は上述の駆動 器用振動子と全く同じものである。 そして, 検出器用振動子 より出された電圧は整流・増幅器で AC-DC 変換, 増幅され, デジタル電圧計で表示されるようになっている。

振動子の共振振動数の測定について，振動子は自身の共振 振動数を持っているから，あらかじめ駆動器用および検出器

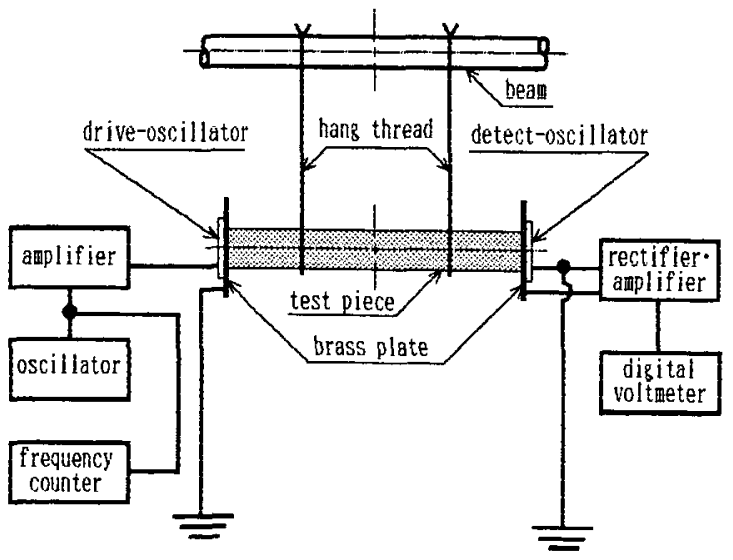

Fig.1 Schematic diagram of the Young's modulus testing apparatus. 
用振動子の共振振動数を測定し，試験片の共振振動数と区別 できるようにして扔かなければならない。そこで，同種の駆 動器用, 検出器用振動子を黄銅板側で両面セロテープまたは 瞬間接着片を用いて結合させたのち測定した。ちなみに，本 実験に使用された振動子自身の共振振動数は 1 次が約 $4 \mathrm{kHz}, 2$ 次が約 $30 \mathrm{kHz} ， 3$ 次が約 $55 \mathrm{kHz}$ ，そして4次が約 $95 \mathrm{kHz}$ となっ ている，試験片への振動子の取り付けについて，(1) 接着面 はあらかじめアセトンで清浄にし，充分に乾燥すること．(2) 試験片端面への振動子の取付には両者の中心の偏差を $2 \mathrm{~mm}$ 下に保つこと. (3) 試験片端面と振動子の黄銅板面との結合 は，両面セロテープを間にはさんで圧着する場合と，瞬間接 着凨を試験片端面と振動子の黄銅板面とに叙ったのちに圧着 する場合などがあったが，とくに瞬間接着郕を塗る場合には， 多孔質試験片内の気孔に接着液が浸入しないよう注意すると ともに接着後充分に乾燥させることなどを行った。

ヤング率は次の式で計算することができる゙3.5.

$$
\mathrm{E}=4 \times 10^{-9} \times \mathrm{L}^{2} \times \rho \times \mathrm{f}^{2}
$$

ここに, E: ヤング率 $\left(\mathrm{N} / \mathrm{mm}^{2}\right), \mathrm{L}:$ 試験片の長さ $(\mathrm{mm}), \rho$ : 試 験片の密度 $\left(\mathrm{g} / \mathrm{cm}^{3}\right), \mathrm{f}$ : 試験片の 1 次共振振動数 $(\mathrm{Hz})$.

\section{3 実験結果及び考察}

Fig.2はSMF 1 種純鉄系の焼結体のヤング率を示したもので

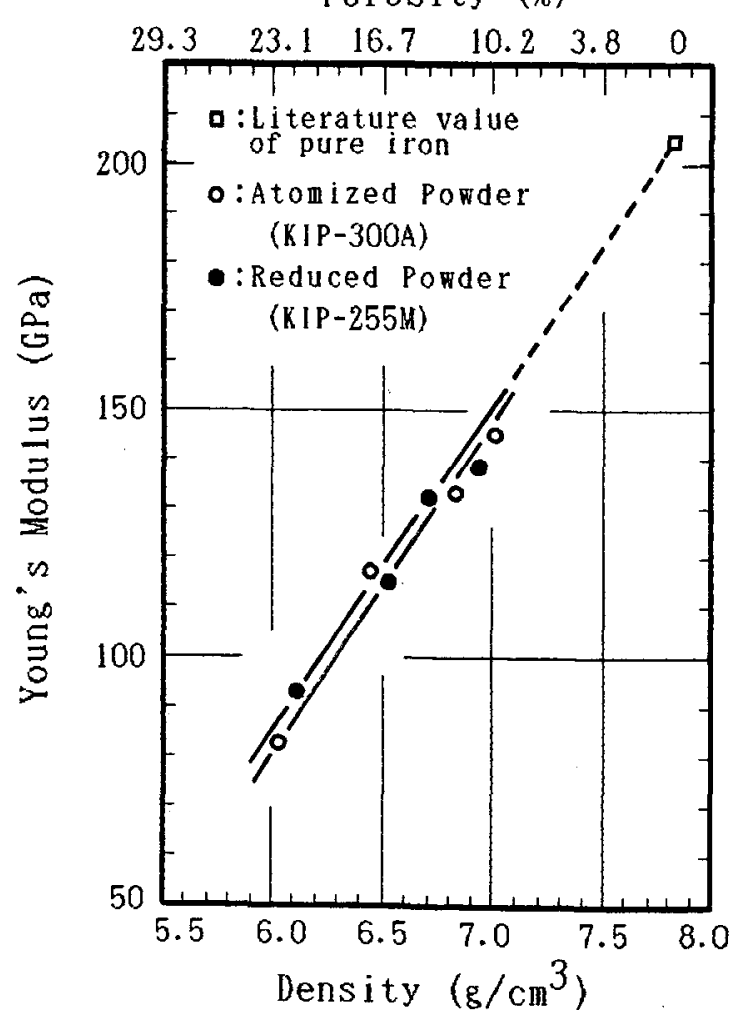

Fig.2 Relations between Young's modulus and sintered density of pure iron powder compacts, sintered at $1423 \mathrm{~K}$ for $1.8 \mathrm{ks}$ in AX atmosphere.
ある．主原料鉄粉は還元鉄粉 (KIP-255M) とアトマイズ鉄粉 (KIP-300A)の2 種類である.両者を比較すると，還元鉄粉と

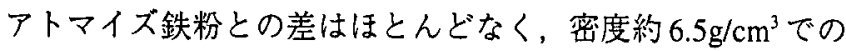
ヤング率は約 $120 \mathrm{GPa}$, 密度約 $7.0 \mathrm{~g} / \mathrm{cm}^{3}$ でのヤング率は約 140GPaである。方なみに，純鉄の文献值は約 206GPaである6。. Fig.3はSMF 2 種, 3 種及び 4 種の鉄一銅、鉄一炭素及び鉄-炭 素ー銅系の焼結体のヤング率を示したものである．各文献值 において，純鉄のヤング率が約 206GPaであるのに対して，純 銅のヤング率は約 $128 \mathrm{GPa}$, 黒鉛のヤング率は約 $11 \mathrm{GPa}$ で両方 ともに低い值でありの，「複合則」に従えば，銅及び黑鉛の添 加の分だけ下がるはずであるが，添加量が比較的少ないため に，それらの差はほとんどみられなかった。たたし，鉄一炭 素系，鉄－銅系，鉄－炭素－銅系の順にヤング率のレベルが 少しずつ低い。すなわちヤング率の低い銅の 1.5 ～5\%の添加 がわずかに影響しているものと考えられる．Fig.4はSMF 5 種, 7 種挹よび 8 種の鉄-炭素-銅ーニッケル系, 鉄ーニッケ ル系及び鉄ー炭素ーニッケル系の烤結体のヤング率を示した ものである。これらの中にはニッケルが最大 $8 \%$ 配合してある が, ニッケルのヤング率文献值は約207GPaで鉄と全く同じで あるのであ殆どその影響はうけていない，また，Fig.4からで は見にくいが，概して鉄ーニッケル系，鉄-炭素ーニッケル 系と銅が含まれている鉄-炭素ー銅ーニッケル系との2つに分 けられそうである。これは銅の影響により銅配合のものにヤ

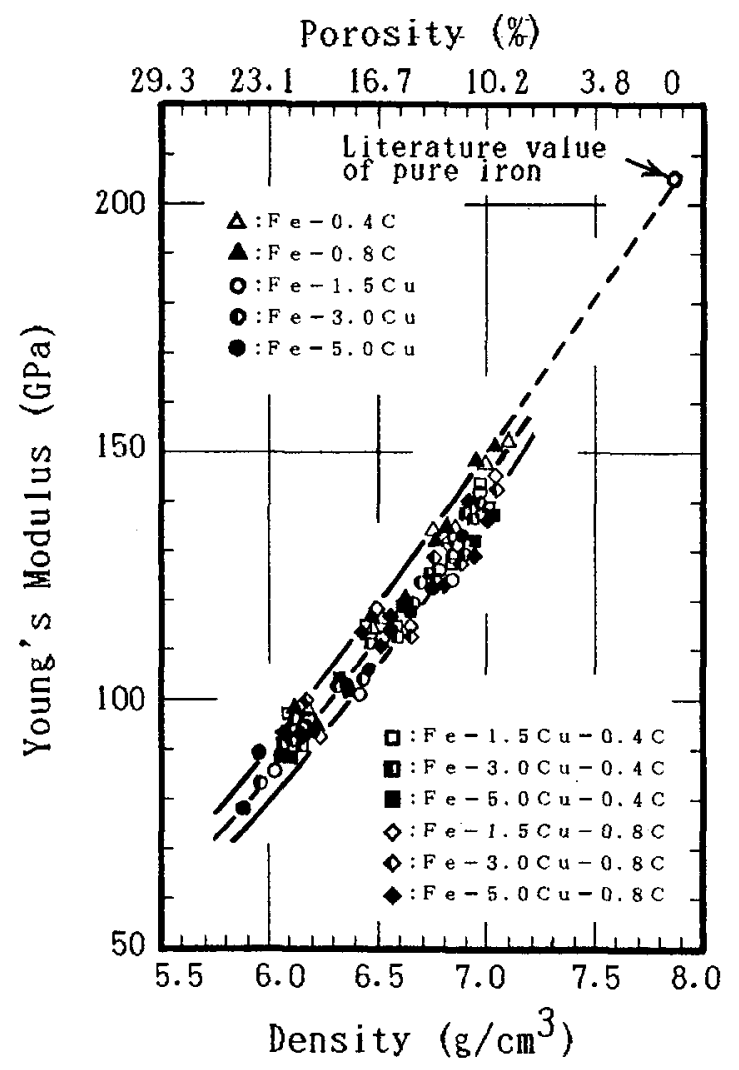

Fig.3 Relations between Young's modulus and sintered density of $\mathrm{Fe}-\mathrm{Cu}, \mathrm{Fe}-\mathrm{C}, \mathrm{Fe}-\mathrm{C}-\mathrm{Cu}$ powder compacts, sintered at $1423 \mathrm{~K}$ for $1.8 \mathrm{ks}$ in $\mathrm{AX}$ atmosphere. 
ング率がわずかに低く出ているためと考えられる.ちなみに， 三浦らもこれらのような各種鉄系焼結材のヤング率に対して, 添加元素の影響はきわめて少ないことを報告している7゙.

Fig.5はSMF 6種の銅溶浸焼結体のヤング率を示したもので

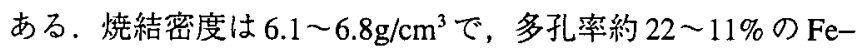
$0.5 \% \mathrm{C}$ 焼結骨格に銅を溶浸した各試料のヤング率を示したも のであるが，文献值において純銅のヤング率は128GPa と純鉄 の206GPaに比べてかなり低いので, この銅溶浸焼結体は銅の 溶浸量が増加して高密度になるほど，ヤング率は低いレベル になる，ちなみに銅 25\%を完全に溶浸した焼結体の密度は約 $8.1 \mathrm{~g} / \mathrm{cm}^{3}$ で，そのヤング率は約 $190 \mathrm{GPa}$ と実験值㧍よび計算か ら推定できる. Fig.6はSMS1種のオーステナイト系316Lステ ンレス鋼およびSMS2種のフェライト采410Lステンレス鋼の 焼結体のヤング率を示したものである．実験結果から見てわ かるようにオーステナイト系316Lのヤング率はフェライト采 410Lのヤング率よりレベルが低い. 文献值において，オース テナイト系 $316 \mathrm{~L}$ ステンレス鋼のヤング率の方が約 $197 \mathrm{GPa}$ と 低く，また, フェライト系410Lステンレス鋼のヤング率が約 204GPaとほぼ純鉄に近くなっている8ことによるものである。 次に焼結雲囲気のうち，特にアンモニア分解ガスでは，焼結 体内のクロム元素が雲囲気中の窒素ガスと反応してヤング率 が高い金属窒化物の窒化クロムを焼結体内に生じるから，ヤ ング率の上昇を予測したが，水素，真空を含めいずれの雾囲

Porosity $(\%)$

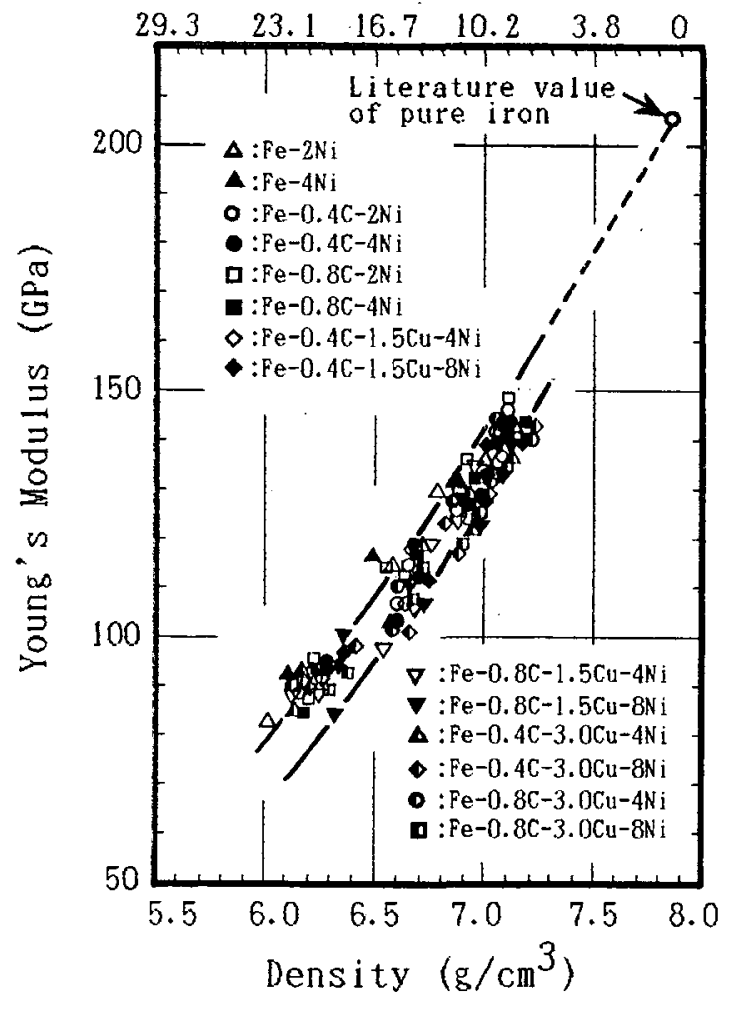

Fig.4 Relations between Young's modulus and sintered density of $\mathrm{Fe}-\mathrm{C}-\mathrm{Cu}-\mathrm{Ni}, \mathrm{Fe}-\mathrm{Ni}, \mathrm{Fe}-\mathrm{C}-\mathrm{Ni}$ powder compacts, sintered at $1423 \mathrm{~K}$ for $1.8 \mathrm{ks}$ in $\mathrm{AX}$ atmosphere.

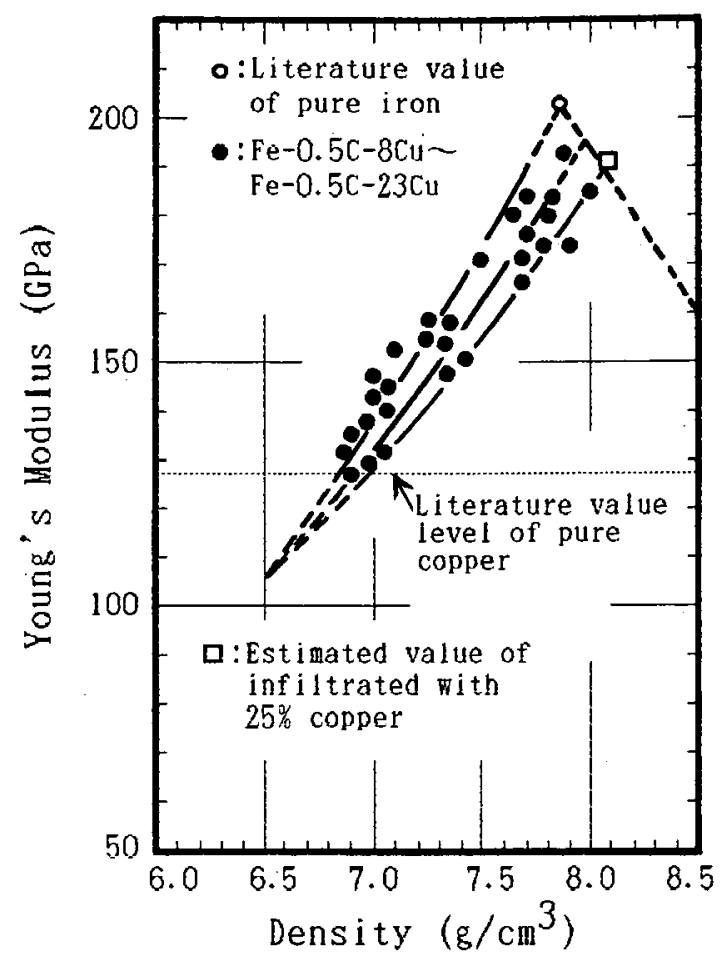

Fig.5 Relations between Young's modulus and sintered density of sintered iron-carbon (copper infiltrated) powder compacts, infiltrated at $1423 \mathrm{~K}$ for $1.2 \mathrm{ks}$ in $\mathrm{AX}$ atmosphere.

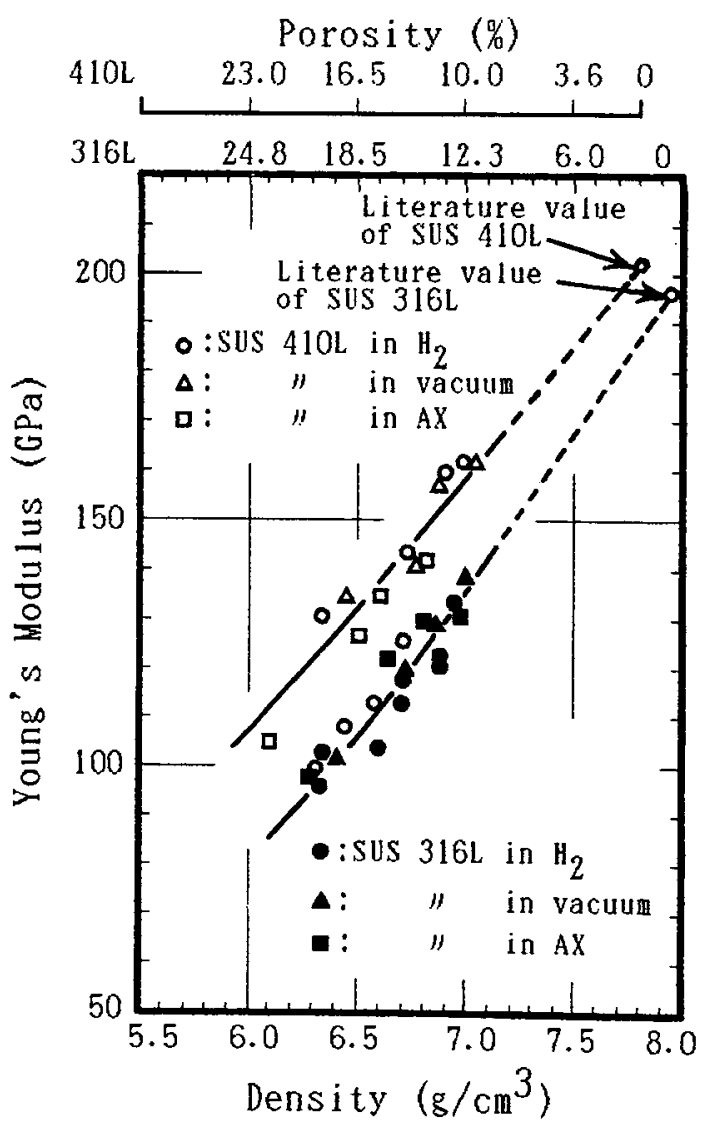

Fig.6 Relations between Young's modulus and sintered density of stainless steel powder compacts, sintered at $1423 \mathrm{~K}$ for $1.8 \mathrm{ks}$ in $\mathrm{H}_{2}$, vacuum and $\mathrm{AX}$ atmospheres. 


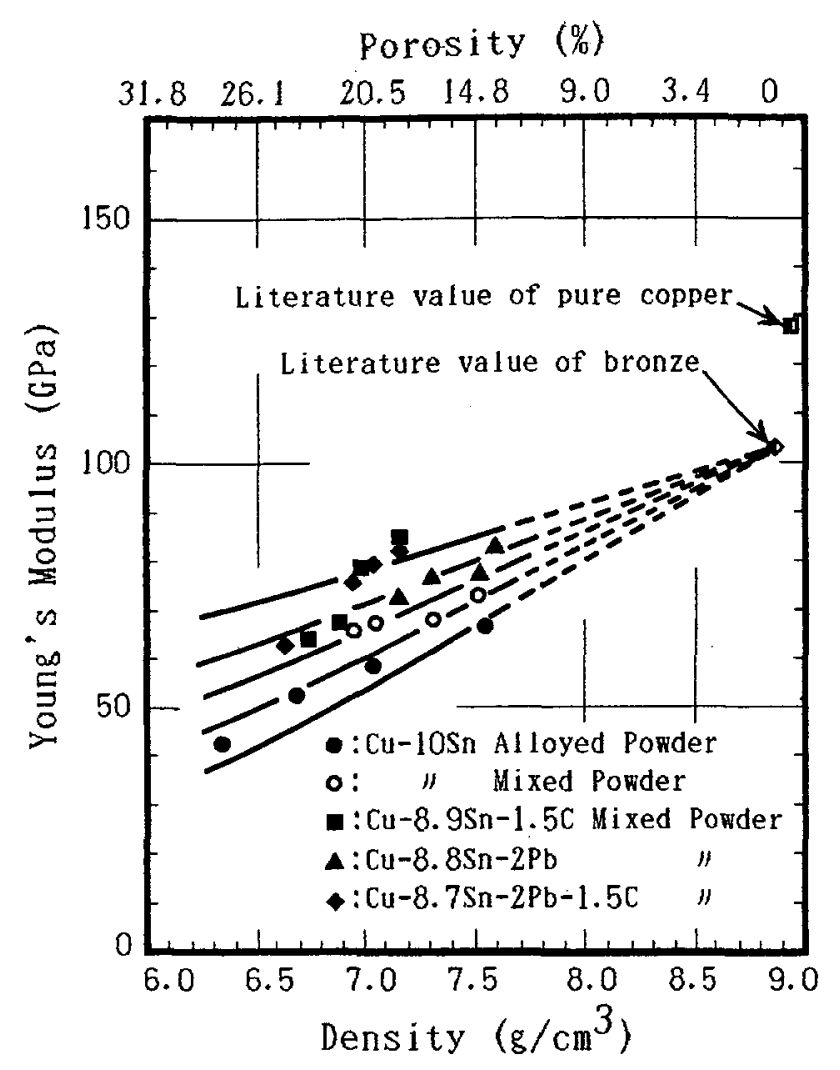

Fig.7 Relations between Young's modulus and sintered density of bronze powder compacts, sintered at $1043 \mathrm{~K}$ for $1.8 \mathrm{ks}$ in $\mathrm{H}_{2}$ atmosphere.

気でも差が認められなかった．窒化クロムの分散量が少ない ためであろう．Fig.7はSMK1種の青銅采の焼結体のヤング率 を示したものである．各焼結体は青銅の文献值であるヤング 率約 103GPaに泊かって密度とともに上昇している形をとっ ているが, それらのレベルはCu-10\%Sn合金粉, Cu-10\%Sn混 合粉系そして鉛を添加したものの順に高くなっている．詳細 は不明であるが，これら混合粉を用いたものでは燒結過程中 に約 10\%の錫とさらに約 2\%の鉛が溶融して液相となるため に，液相焼結によって気孔の形状が球形(丸みを帯び)となり
易く”，従って，焼結体の強さ (剛性)が増してその結果ヤン グ率が向上したためと考えられる。

$$
4 \text { まとめ }
$$

以上, 機械構造部品用各種焼結材料について, それらのヤ ング率を測定した結果を紹介した，各種焼結材料のヤング率 值とそれらヤング率值に及ほすす焼結密度の影響を示しただけ で，まだ充分な説明は加えられなかったが，今後それらの表 付けを逐次進めて行きたいと思っている。

\section{謝 辞}

実験にご協力いただいた早稲田大学理工学部卒業生の伊藤 宏樹, 宇野登, 佐藤宗昭, 佐藤 宏, 小川博, 岡松参次郎, 河 村徽生，土谷健二，根本敦の各氏に感謝致すとともに，本報 をまとめるにあたり，終始ご支援とご指導をいただいた日産 自動車(侏技師藤木章氏，フクイシンター(侏社長西村実氏，部 長伊藤敏直氏，部長横山 周氏に感謝の意を表します。

$$
\text { 文献 }
$$

1) 日本工業標準調查会: JIS Z 2280 "金属材料の高温ヤング 率試験方法 ", (1993)1-10.

2) 精機学会, 計測自動制御学会共編: 改訂工業測定便覧, コ 口ナ社, (1964)849.

3）渡辺㐳尚："燒結金属のヤング率に対する動的および静的 測定法に関主る研究", 材研報告, 50(1994)38-45.

4) 日本粉末冶金工業会: JPMA M 10 "焼結金属材料のヤング 率試験方法", (1997)3-7

5) Inter. Organization for Standard: ISO 3312 "Sintered Metal Materials-Determination of Young's Modulus", (1975)1-2.

6) 日本機械学会編：機械工学便覧改訂 5 版, 日本機械学会, (1968)4-7.

7) 三浦秀士, 坂本愛一郎, 徳永洋一: "鉄系烵結材のヤング率 に及はす気孔率と気孔形状の影響”, 粉体拉よび粉末冶金, 27(1980)82-87.

8）大同特殊鋼制編：特殊鋼ハンドブック，大同特殊鋼(侏), (1993)246. 